\title{
SELECTED HEALTH BEHAVIOURS OF NURSES
}

UDK: 159.9

\section{Maria Chuchra}

The Head of Department of Public Health, John Paul II Catholic University of Lublin, Lublin (Poland)

ORCID ID: https://orcid.org/0000-0001-7734-9866

\section{Julia Gorbaniuk}

The Professor of Department of Public Health, John Paul II Catholic University of Lublin, Lublin (Poland)

\begin{abstract}
ORCID ID: https://orcid.org/0000-0001-7732-7819

Currently, the role of nurses in healthcare is growing. Each day more demanding and responsible, practical tasks are put in front of them. They also have a leading role in the field of health promotion and professional knowledge about a healthy lifestyle. Due to their medical knowledge, they are expected to have a conscious, rational and critical attitude towards shaping and observing prohealth behaviours in their lives. The aim of this study is to compare the selected health behaviours of nurses. The research included 100 nurses and 100 women doing other professions. The respondents were tested with the matched pair-selection method, taking into consideration two variables: place of residence and age. The survey questionnaire was used. The nurses show similarities with respect to some health behaviours and show significant differences in the consumption of alcoholic beverages (the amount and kind) or regularity of preventive checks in comparison to others. The profession of nurses due to its' specificity and requirement of constant care for ill person results in a very high level of stress. Nurses feel permanent pressure, which entails permission to use stimulants such as coffee, alcohol and to a lesser extent - smoking. Their role as promoters of a healthy lifestyle means that they try to take care of health through control or preventive examinations.
\end{abstract}

Key words: health behaviours, nurses, women, health psychology.

\section{INTRODUCTION}

The profession of a nurse in Poland occu- pies a high position in the hierarchy of prestige, outperforming even the profession of a doctor 
which is always respected and appreciated. This is proven by the results of research carried out over the years [1, 2]. However, in the situation of assessing fairness and professional integrity, the nursing profession was rated the highest and ranked first [3]. The role of nurses in healthcare is growing. Each day more demanding and responsible practical tasks are put in front of them. They also have a leading role in the field of health promotion and professional knowledge about a healthy lifestyle [4]. Because of their medical knowledge, they are expected to have a conscious, rational and critical attitude towards shaping and observing pro-health behaviours in their lives. However, possessing the appropriate theoretical knowledge does not necessarily result in its use in life, even though health's significance is particularly valued by nurses $[5,6]$. Nevertheless, wanting to be reliable and convincing for the patient, they must believe in the validity of the promoted content, apply it in practice and to be a role model for the patient. As the research shows, nurses who are actively exercising, non-smoking or those who follow a balanced diet are more likely to promote a healthy lifestyle than those who do not observe pro-health recommendations $[7,8,9]$. On the other hand, patients are more likely to follow the recommendations for a correct diet or physical exercise and show greater confidence in nurses who have appropriate body mass [10]. There are many studies conducted in various parts of the world, which emphasize the unsatisfactory level of health behaviours in the lives of nurses [11, 12, 13], in such situation, they cannot be an authority for patients whom they nurse and educate. The results, however, are not unambiguous. Some highlight that young people in particular do not pursue pro-health in their lives, although during their education they received a greater range of current information in this field than their older colleagues $[11,12]$.

In health psychology, health behaviours are divided into habitual and purposeful. Habitual behaviours are related to the hygiene of everyday life, eating habits, physical activity and rest. They result from socialization and cultural influences. On the other hand, purposeful behaviours are initiated in specific situations related to promotional and preventive activities and appear in situations of life and development changes [14].

This article will show selected health behaviours of nurses, in comparison to their peers who are engaged in professions that are not related to health care.

\section{AIM}

The aim of this article is to characterise selected health behaviours of professionally active nurses.

\section{MATERIAL AND METHODS}

In order to answer the basic research questions, 100 nurses and 100 women from the control group belonging to different professional groups were examined. The demographic variables were controlled by matching persons using the pair-selection method, taking into consideration two variables: place of residence (village, 
city) and age of the respondents. It has been assumed that controlling these two variables will eliminate some of the important factors that affect the occurrence of certain nurses' behaviour compared to other professional groups. The nurse research group was represented by women aged between 23 and 60 . The average age was $M=39$, 5 . They were women who mostly lived in cities $60 \%$ and $40 \%$ of women came from the village. The control group consisting of women working in other professions was analogous in terms of these two variables.

Education in both groups was represented in three categories: secondary vocational $(28 \%$ nurses and 34\% - control group), higher vocational at bachelor level (34\% - nurses and 26\% - control group) and master's degree (38\% - nurses and $40 \%$ - control group). The examined women had a similar marital status; married women were rep- resented by $70 \%$ of female nurses and $63 \%$ of women from the control group, unmarried woman by $17 \%$ of nurses and $21 \%$ of women from the control group and divorced women were represented by 6 nurses and 4 people from the control group. Other marital statuses were very similarly represented by women qualified for both groups.

The research used a questionnaire built for the study Lifestyle of men and women, consisting of 79 questions. In the article only its fourth part is used- selected questions related to pro-health and anti-health behaviours. In order to determine the statistical differences between the two groups, the Mann-Whitney U test was used.

\section{RESULTS}

In the first place, the examined persons were asked what is most harmful to their health. The respondents could choose from the following answers: stimulants, non-compliance with healthy

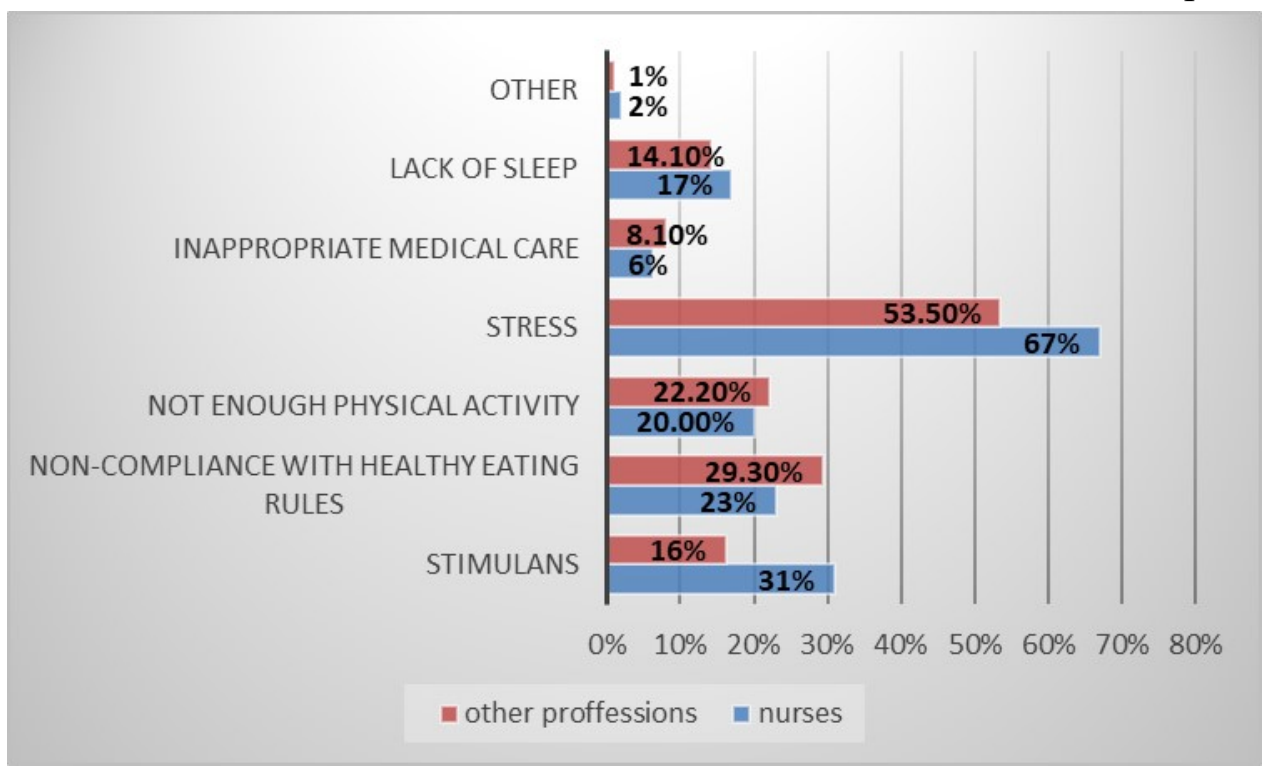

FIGURE 1. Factors most harmful to the health

(Chi-square $=6,072, \mathrm{df}=1, \mathrm{p}=0,01)$ 
eating rules, not enough physical activity, stress, inappropriate medical care, lack of sleep and other situations which, in their opinion, have significant impact on health. The results are shown in Figure 1.

When comparing factors most harmful to nurses' health in comparison with other professions, it is noted, that in most aspects there is a large similarity in the responses. According to the respondents, their health is mostly harmed due to stress. Almost $67 \%$ of nurses report that they experience this condition at work regularly, while women working in other professions (54\%) indicate this fact less frequently $(\mathrm{p}=0.05)$. Similarly crucial for all examined is the problem of noncompliance with the rules of healthy nutrition (nurses - 23\% and other professions - 30\%). Insufficiency in physical activity was pointed out by less than one-fifth of all women surveyed (nurses - 20\% and other professions - 22\%). A similar number of people indicated the lack of proper length of sleep (nurses - 17\% and other professions - 14\%). A comparable number of people indicated the lack of proper amount of sleep (nurses - 17\% and other professions - 14\%).
Noteworthy is the fact that in terms of the use of stimulants (alcohol, coffee, cigarettes, energy drinks and others) a statistically significant difference was observed in the statements of both groups of women $(p=0.01)$. Nearly one third of nurses $(31 \%)$ said that stimulants are an important factor that harms their health, while among women working in other professions, less than one fifth of respondents believe that $(16.2 \%)$. In order to specify what type of stimulants differentiate nurses and women from the control group, the respondents were asked to determine the frequency of alcohol consumption and smoking.

The results contained in tab. 1 show that both groups of women smoke cigarettes as much as they consume alcohol. Smoking in both groups: nurses and women in other professions remains at a similar, moderate level. The dispersion of the results indicates that in both groups, women smoke cigarettes habitually (about 10\%), and similar percentages of women (about 10\%) declare that they used to smoke cigarettes. Among the respondents declaring that they smoke occasionally in various life and social sit-

TAB. 1. Smoking cigarettes and drinking alcohol by nurses compared to the control group

\begin{tabular}{|c|c|c|c|c|c|c|c|}
\hline \multicolumn{2}{|l|}{ Stimulants } & $N$ & $M$ & $s d$ & $t$ & $d f$ & $p$ \\
\hline Smoking cigarettes & Nurses & 100 & 3,40 & 1,015 & \multirow[b]{2}{*}{0} & \multirow[b]{2}{*}{198} & \multirow[b]{2}{*}{0,268} \\
\hline & $\begin{array}{l}\text { Other profes- } \\
\text { sions }\end{array}$ & 100 & 3,40 & 1,128 & & & \\
\hline \multirow[t]{2}{*}{ Drinking alcohol } & Nurses & 100 & 3,65 & 0,857 & \multirow[b]{2}{*}{$-0,964$} & \multirow[b]{2}{*}{198} & \multirow[b]{2}{*}{0,61} \\
\hline & $\begin{array}{l}\text { Other profes- } \\
\text { sions }\end{array}$ & 100 & 3,76 & 0,754 & & & \\
\hline
\end{tabular}


uations, there were $11 \%$ of nurses and $12 \%$ of women from the control group. As the results of the research show, in the situation of smoking cigarettes, the attitudes are more extreme: either they smoke habitually or not at all, and only a small group of people fall into the category of occasional smokers. Among the respondents about $70 \%$ of nurses declare that they never smoked cigarettes compulsively, while among women in the control group - about $60 \%$. Overall, it should be pointed out that the average responses for both groups due to smoking were identical.

Alcohol consumption also occurs at a very similar rate in both groups of women and falls within the range of the answer from "I rather not drink" to "I drink sometimes" during special

\section{Tab. 2. The kind of alcohol drunk}

\begin{tabular}{|l|c|c|c|c|c|}
\hline Kind of alcohol & Nurses & $\begin{array}{c}\text { Other profes- } \\
\text { sions }\end{array}$ & Chi-square & $d f$ & $p$ \\
\hline vodka & $13 \%$ & $10 \%$ & $0,364^{\mathrm{a}}$ & 1 & 0,547 \\
\hline wine & $52 \%$ & $34 \%$ & $5,114^{\mathrm{a}}$ & 1 & 0,015 \\
\hline beer & $12 \%$ & $31 \%$ & $7,185^{\mathrm{a}}$ & 1 & 0,014 \\
\hline liqueurs & $17 \%$ & $9 \%$ & $1,177^{\mathrm{a}}$ & 1 & 0,097 \\
\hline do not drink at all & $6 \%$ & $16 \%$ & $4,009^{\mathrm{a}}$ & 1 & 0,045 \\
\hline
\end{tabular}

events and circumstances. The vast majority of nurses said they consume alcohol sometimes $(37 \%)$ or rarely (49\%). Among nurses, 4\% reported that they consume alcohol on the daily-basis, while women working in other professions did not indicate this type of frequency. Nurses who declared themselves as not drinking any alcohol represent about $10 \%$ of the respondents, while among women doing other professions, the number was close to approximately $20 \%$.

Analysis of the collected material indicates that the difference between the two groups of women in terms of alcohol consumption is not only quantitative (frequency of consumption), but also qualitative (the type of alcohol). Nurses definitely prefer wines $(\mathrm{p}=0.01)$ or liqueurs, at the same time much less frequently reach for beer or other home-made alcohols that are consumed by the groups in other professions $(p=0.01)$. Analysing the attitude of women against the consumption of alcohol, it was found that women doing other professions are more often inclined to this type of attitudes and behaviours than women who work as nurses $(p=0.05)$. 
Tab. 3. Pro-health behaviours

\begin{tabular}{|c|c|c|c|c|c|c|}
\hline \multirow[t]{2}{*}{ Questions } & \multicolumn{2}{|c|}{ Nurses } & \multicolumn{2}{|c|}{ Other professions } & \multicolumn{2}{|c|}{$\begin{array}{c}\text { U- Man Witney } \\
\text { Test }\end{array}$} \\
\hline & $M$ & $s d$ & $M$ & $s d$ & $z$ & $p$ \\
\hline 53. Do you regularly do any physical activities? & 3,10 & 0,931 & 3,12 & 0,891 & $-0,147$ & 0,441 \\
\hline $\begin{array}{l}70 . \text { Is physical activity connected with health, in } \\
\text { your opinion? }\end{array}$ & 4,31 & 0,662 & 4,37 & 0,597 & $-0,673$ & 0,401 \\
\hline 38. Do you think your diet is healthy? & 3,11 & 0,952 & 2,96 & 0,942 & 1,120 & 0,338 \\
\hline $\begin{array}{l}\text { 78. Do you regularly undergo basic examina- } \\
\text { tions? }\end{array}$ & 3,84 & 0,950 & 3,13 & 1,116 & 4,843 & 0,001 \\
\hline 79. Do you undergo preventive checks? & 3,91 & 0,922 & 3,05 & 1,095 & 5,783 & 0,001 \\
\hline 69. Do you think you lead a healthy lifestyle? & 3,22 & 0,917 & 2,93 & 1,167 & 2,242 & 0,825 \\
\hline
\end{tabular}

aminations $(\mathrm{z}=4.843, \mathrm{p}=0.001)$ and prophylac- relationship to health. When answering a question tic $(\mathrm{z}=-5.783, \mathrm{p}=0.001)$, to the disadvantage of about healthy eating, both, nurses and women women working outside the health care system. working in other professions more often chose On the other hand, there were no statistically sig- the middle options. Such a low indicator of exnificant differences in physical activity between treme answers may suggest that the respondents the two groups studied, healthy eating and their are not sure whether they have appropriate eating

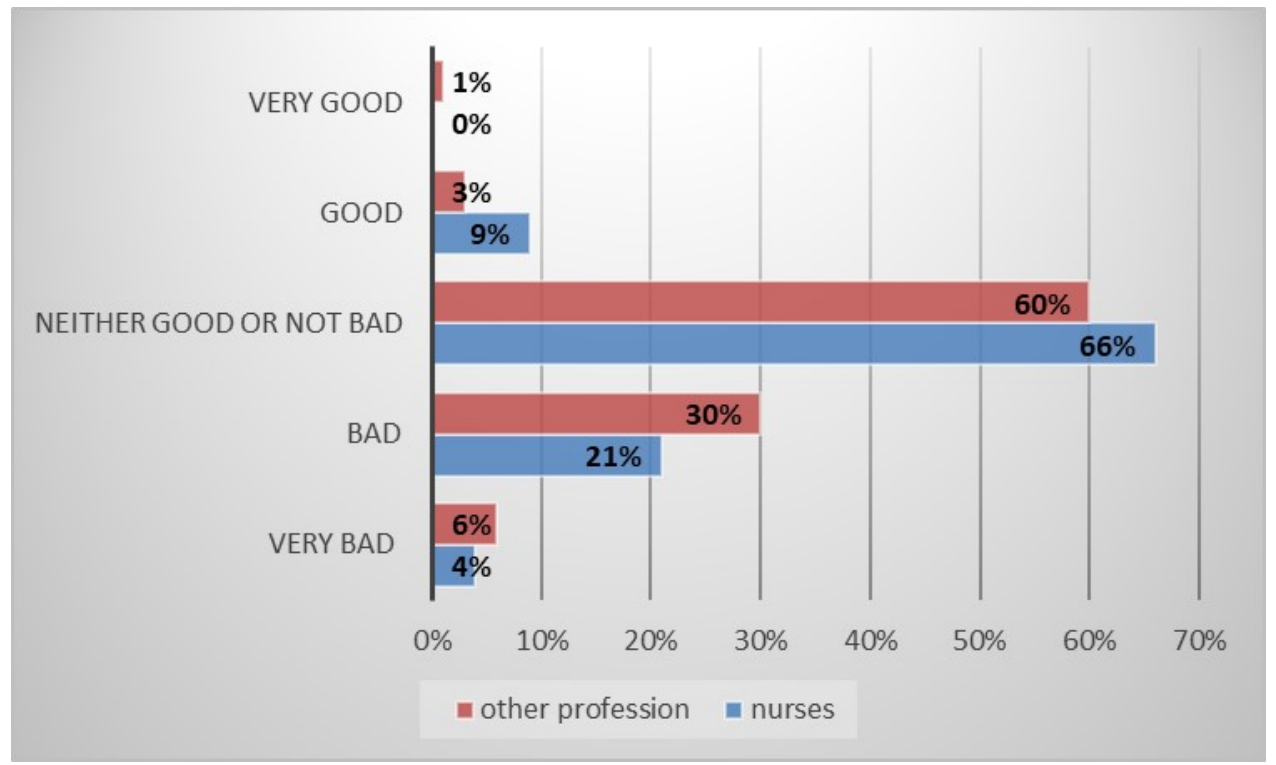

Chart 2. Assessment of one's own health conditions

(Chi-square $=6,274, \mathrm{df}=4, \mathrm{p}=0,180$ ) 
habits.

In the following question, the respondents were asked to evaluate, as generally as possible, their current health condition. The results are shown in Figure 2.

The results show that both nurses and women from the control group perceive their health condition very similarly. The greatest number of people chooses the answer that their health condition is "neither good nor bad' (nurses - 66\% and other professions $60 \%$ ). $25 \%$ of nurses and $36 \%$ of women in the control group see their health as "bad" or "very bad", while $9 \%$ of nurses and only $3 \%$ of women working in other professions rated their health as good. Out of 200 respondents taking part in the research, only one evaluated her health condition as 'very good'.

Looking for correlation between one's own health assessment and the frequency of smoking and drinking alcohol, with the help of Kendall rank correlation coefficient for pairs, it was found that there is an inverse relationship between the frequency of smoking and the general evaluation of one's own health condition (tau $-b$ Kendall $=-0,172, p=0,013)$. This kind of relationship was not found between the evaluation of one's own health condition and excessive alcohol consumption $($ tau- $b$ Kendall $=-0,046, \mathrm{p}=$ $0,287)$. The respondents who frequently consume alcohol claim that such alcoholic beverages as beer or wine, despite being drunk regularly or often, do not harm their health as much as nicotine.

At the final stage of the research, the respondents were asked if they cared for their health condition. The results are shown in Figure 3.

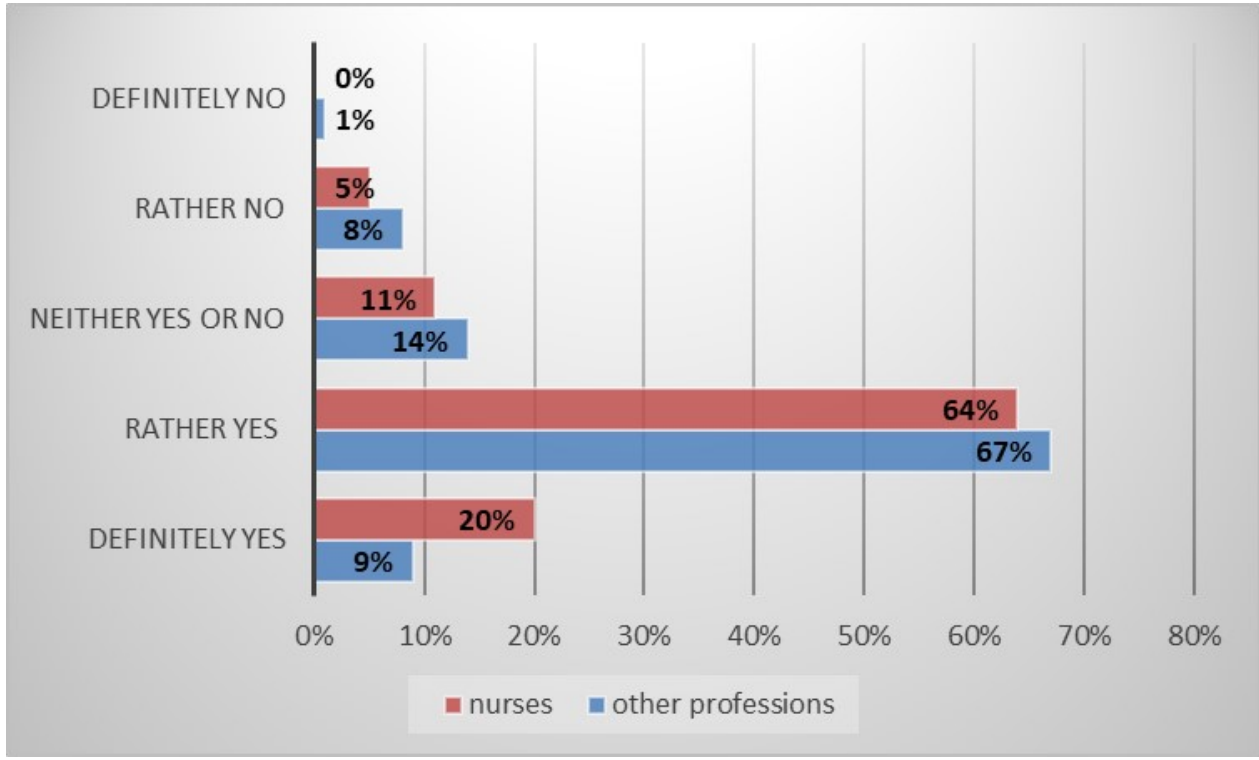

FIGURE 3. The assessment of the care for one's own health condition (Chi- square $=7,293, \mathrm{df}=4, \mathrm{p}=0,200$ ) 
Analysing the respondents' answers, it may be concluded that a vast majority of surveyed women show a high awareness related to taking care of their own health. The total of $84 \%$ nurses and $76 \%$ of women from the control group indicated that they take fairly good care of their health or that it is definitely important to them. A small part of women from both groups answered that they do not care about their health or have an indifferent attitude towards it (nurses - 5\% and other professions - 9\%).

Both nurses and women representing other professions care about their own health. However, women from the control group more often indicate rather interim activities with preventative character $(67 \%)$, while $77 \%$ of nurses regularly care about health problems through medical examinations, also having greater awareness of the consequences of these neglects for the further course of the illness and its treatment. In turn, a systematic pro-health attitude (e.g. sports and general fitness exercises) concerns $16 \%$ of women working in other professions and only $6 \%$ of nurses. Among the group of women who declared high awareness of the need to take care of their own health, the vast majority of people (around 87\%) found that they completely do not consume alcohol and about $79 \%$ who do not smoke or never smoked cigarettes habitually.

\section{DISCUSSION}

Analysing the health behaviours of nurses and women working in other professions, unrelated to health care, the first to be compared are the factors that respondents claimed to harm their health the most. Among the mentioned factors, the first place in both groups occupied stress, which for nurses is significantly more intense $(p=0.5)$. Stress, as an inseparable element of nurses' work, is emphasised in many publications [9, 15, 16, and 17]. It makes it impossible to focus on the tasks performed, causes loss of motivation to work and triggers many unpleasant symptoms. However, among the most differentiating factors for both groups are stimulants (cigarettes, alcohol, and coffee). Almost one third $(31.0 \%)$ of nurses reported that stimulants are an important factor that harms their health $(\mathrm{p}=0.1)$, while among women in the control group there is less than one fifth of them $(16.2 \%)$. A more detailed analysis shows that smoking in both groups is maintained at a similar, moderate level, and approximately $10 \%$ of women are addicted to nicotine in both groups. In turn, $70 \%$ of nurses declare that they did not smoke cigarettes, while in the control group it is $60 \%$ of women surveyed. The obtained results are similar to those received by A. Remigrońska and A. WłoszczakSzubzda. In their research, nurses also excessively used stimulants and the vast majority (78\%) did not smoke cigarettes [9]. Polish nurses, compared to their colleagues from Ireland perform better, as $56 \%$ of nurses were non-smokers according to research in this country [18], and less favourably than nurses in Australia, among whom $87 \%$ of respondents were non-smokers 
[11].

Drinking also occurs at a very similar frequency in both groups and usually takes place during special events. The significant difference concerns the type of alcohol consumed. Nurses definitely prefer more exquisite and more expensive alcohols, while women from the control group reach for more available ones like beer or other home-made alcohols $(\mathrm{p}=0.1)$. Among women doing other professions there are more abstinent than among nurses $(p=0.05)$. In this study $37 \%$ of nurses consume alcohol at times, $49 \%$ rarely, and $10 \%$ are non-drinkers. In the Remigronska and Włoszczak-Szubzda research [9], nurses who drink alcohol occasionally were $67 \%$ and abstainers 22\%. In Australian studies nurses had higher scores than the general Australian population, indicating risky drinking [11]. Nurses also drink a lot of coffee, because more than three -quarters of the respondents (76.7\%) say that it is the most frequently consumed drink. Noteworthy, is the fact that smokers, when assessing their state of health, perceive certain ailments as the effects of smoking, while people who drink alcohol do not notice such dependence. However, this is not something typical for nurses, because such regularities were also noticed in other groups of respondents [19].

When comparing pro-health behaviours such as: physical activity, correct eating habits, performing periodic and prophylactic examinations, it was found that women from both groups differ significantly in terms of regularity of medi- cal and prophylactic examinations $(\mathrm{p}=0.001)$. Nurses in regard to this are distinctly more advantageous as they systematically carry out preventive examinations, while women from the control group - interim. This may result not only from a greater awareness of the consequences of negligence, but also from easier access to medical facilities. Nonetheless, there were no differences in physical activity, nutrition or perception of health condition, although many publications report negligence in these aspects of lifestyle. In the studies of M. Muszalik et al. low physical activity, irrational nutrition and overweight as well as the low number of preventive examinations being done by nurses were the greatest threat to their health [20]. Nurses in other countries have similar problems [11, 13, 21, and 22]. The reasons mentioned for this state are, among others, overburden, stress and shift work.

\section{CONCLUSIONS}

According to nurses the factors that harm health the most are stress and stimulants.

The vast majority of nurses do not smoke and occasionally consume alcohol.

Nurses regularly carry out medical and prophylactic examinations, while women from the control group carry out interim medical examinations.

\section{References:}

1.Prestiż zawodów, Komunikat z badań CBOS, Warszawa 2009; 8:1-9. 
2. Prestiż zawodów, Komunikat z badań CBOS, Warszawa 2013; 164:1-11.

3. Społeczne oceny uczciwości i rzetelności zawodowej, Komunikat z badań CBOS, Warszawa 2016;34:1-11.

4. Didenko O. D., Role of nurses in promoting healthy lifestyles and physical activity, Медсестринство, 2014; 3:3740.

5. Deluga A., Dobrowolska B., Kosicka B., Brzozowska A., Wartościowanie zdrowia $\mathrm{W}$ opinii pielęgniarek $\mathrm{W}$ odniesieniu do zmiennych społeczno - demograficznych, „Jour-nal of Education, Health and Sport” 2016; 6(4):167180.

6. Deluga A., Dobrowolska B., Kosicka B., Ślusarska B., Jędrych M., Brzozowska A., Znaczenie zdrowia w hierarchii wartości osobistych pielęgniarek, „Studia Medyczne” 2018; 34(1): 64-69.

7. Rush K.L., Kee C.C., Rice M.. Nurses as imperfect models of health promotion. West. J. Nurs. Res. 2005; 27 (2):166-183.

8. Radsma J., Bottorff J.L. Counteracting ambivalence: nurses who smoke and their health promotion role with patients who smoke. Res. Nurs. Health. 2009,32:443-52.

9. Remigrońska A., Włoszczak-Szubzda A. Zachowania zdrowotne pielęgniarek czyn-nych zawodowo co najmniej jeden rok. „Aspekty Zdrowia i Choroby” 2016; 1(1):41-53. 10. Hicks M., McDermott L.L., Rouhana N., Schmidt M., Seymour M.W., Sullivan T. Nurses' body size and public confidence in ability to provide health education. J. Nurs. Scholarsh. 2008;40(4):349-54.

11. Perry L., Xu X., Gallagher R., Nicholls R., Sibbritt D., Duffield Ch. Lifestyle Health Behaviors of Nurses and Midwives: The 'Fit for the Future' Study. Int. J. Environ. Res. Public Health 2018; 15(5), 945; doi:10.3390/ ijerph15050945

12. Jankowska-Polańska B., Wijacka K., Lomper K., Uchmanowicz I. Zachowania zdro-wotne personelu pielęgniarskiego w profilaktyce nadciśnienia tętniczego. Współczesne Pielęgniarstwo i Ochrona Zdrowia 2014; 3(3):67-70.

13. Zapka J. M., Lemon S. C., Magner R. P., Hale, J. Life- style behaviours and weight among hospital-based nurses. J. Nurs. Manage. 2009;17(7):853-60.

14. Sęk H. Zdrowie behawioralne. [w:] J. Strelau (red): Psychologia - Podręcznik akade-micki. Jednostka w społeczeństwie i elementy psychologii stosowanej. T.3. GWP. Gdańsk 2005:533-553.

15. Stępień M., Szmigiel M. Stres personelu pielęgniarskiego związany $\mathrm{z}$ pracą na oddzia-łach pediatrycznych. Pielęgniarstwo Polskie 2017; 63(1):62-68.

16. Mackenzie C.S., Poulin P.A., Seidman-Carlson R. A brief mindfulness-based stress reduction intervention for nurses and nurse aides. Applied Nursing Research 2006;19:105-109.

17. Beck. Ch.T. Secondary Traumatic Stress in Nurses: A Systematic Review. Archives of Psychiatric Nursing 2011; 25(1):1-10.

18. O`Donowan G. Smoking prevalence among qualified nurses in the Republic of Ireland and their role in smoking cessation. Int Nurs Rev. 2009;56(2):230-236.

19. Chuchra M, Gorbaniuk J. Selected health behaviours in professionally active men and women. Pol. J. Public Health 2017;127(2):205-208

20. Muszalik M., Kędziora-Kornatowska K., Marzec A., Klawe J. Analiza zachowań zdrowotnych, samooceny oraz zagrożeń zdrowia pielęgniarek studiujących zaocznie. Problemy Higieny i Epidemiologii 2017;88(3):354-359.

21. Bakhshi S., Sun F., Murrells T., While A. Nurses' health behaviours and physical ac-tivity-related health-promotion practices. Br. J. Community Nurs. 2015;20(6);289-296.

22. KellyM., Wills J., Sykes S. Do nurses' personal health behaviours impact on their health promotion practice? A systematic review. Int. J. Nurs. Stud. 2017;76:6277. 


\section{Мария Чучра}

Начальник управления общественного здравоохранения, Люблинский католический университет Иоанна Павла II, г. Люлин (Польша)

\section{Юлия Горбанюк}

Профессор кафедры общественного здравоохранения, Люблинский католический университет Иоанна Павла II, г. Люлин (Польша)

\section{ИЗБРАННОЕ ПОВЕДЕНИЕ ЗДОРОВЬЯ МЕДСЕСТРОВ}

\section{Аннотация}

В настоящее время роль медсестер в здравоохранении возрастает. Каждый день перед ними ставятся все более сложные и ответственные практические задачи. Они также играют ведущую роль в области укрепления здоровья и профессиональных знаний о здоровом образе жизни. Ожидается, что благодаря своим медицинским знаниям они будут иметь осознанное, рациональное и критическое отношение к формированию и наблюдению за здоровым поведением в своей жизни. Целью данного исследования является сравнение выбранного поведения медсестер в отношении здоровья. В исследование были включены 100 медсестер и 100 женщин, занимающихся другими профессиями. Респонденты были протестированы с использованием метода парного отбора с учетом двух переменных: места проживания и возраста. Опросный лист был использован. Медсестры демонстрируют сходство в отношении некоторых видов поведения в отношении здоровья и показывают существенные различия в потреблении алкоголь- ных напитков (количество и вид) или регулярность профилактических осмотров по сравнению с другими. Профессия медсестер из-за ее специфики и необходимости постоянного ухода за больным человеком приводит к очень высокому уровню стресса. Медсестры испытывают постоянное давление, которое влечет за собой разрешение на использование стимуляторов, таких как кофе, алкоголь и в меньшей степени - курение. Их роль как пропагандистов здорового образа жизни означает, что они пытаются заботиться о здоровье посредством контрольных или профилактических осмотров.

Ключевые слова: здоровое поведение, медсестры, женщина, психология здоровья.

\section{Марія Чухра}

Начальник відділу охорони здоров'я, Люблінський католицький університет ім. Івана Павла II, м. Люблін (Польщза)

\section{Юлія Горбанюк}

Професор кафедри охорони здоров'я, Люблінський католицький університет Іоанна Павла II, м. Люблін (Польщза)

\section{ВИБРАНІ МОДЕЛІ ЗДОРОВОЇ ПОВЕДІНКИ МЕДСЕРСІВ}

Анотація. Наразі зростає роль медсестер у сфері охорони здоров'я. Кожен день більш вимогливі і відповідальні, перед ними ставлять практичні завдання. Вони також мають провідну роль у сфері зміцнення здоров'я та професійних знань про здоровий спосіб життя. Завдяки своїм медичним знанням, вони 
повинні мати свідоме, раціональне та критичне ставлення до формування та дотримання поведінки про-здоров'я у своєму житті. Метою даного дослідження $є$ порівняння обраної медичної поведінки медичних сестер. Дослідження включало 100 медсестер і 100 жінок, що займаються іншими професіями. Респонденти тестувалися методом підбору парної пари, враховуючи дві змінні: місце проживання та вік. Було використано опитування. Медсестри виявляють подібність 3 деякою поведінкою здоров'я і демонструють значні відмінності в споживанні алкогольних напоїв (кількість і вид) або регулярність профілактичних перевірок у порівнянні з іншими. Професія медсестр через свою специфіку та вимогу постійного догляду за хворими призводить до дуже високого рівня стресу. Медсестри відчувають постійний тиск, що тягне за собою дозвіл на використання стимуляторів, таких як кава, алкоголь і в меншій мірі - куріння. Їх роль як пропагандистів здорового способу життя означає, що вони намагаються піклуватися про здоров'я через контроль або профілактичні огляди.

Ключові слова: здорова поведінка, медсестри, жінки, психологія здоров'я. 